\title{
Systemic Approach to e-Skilling in South Africa
}

\author{
Zoran Mitrovic \\ University of the Western \\ Cape, Bellville, South Africa
}

zmitrovic@uwc.ac.za

Wallace Taylor

The Information Society

Institute, Cape Town, South Africa

wallace.j.taylor@gmail.com

\author{
Mymoena Sharif \\ e-Skills Institute, DoC, Pretoria, \\ South Africa
}

mymoena@doc.gov.za

Harold Wesso

e-Skills Institute, DoC, Pretoria, South Africa

\section{haroldw@doc.gov.za}

\begin{abstract}
There is widespread agreement of the importance of information and communication technologies (ICT) in building equitable prosperity and globally competitive economies. Effective use of these technologies, however, requires building new capacities and skills, here referred to as eskills, not only in the working force but the entire population. These skills are in very short supply all over the developing world, and are of particular concern in South Africa. In order to appropriately address this issue, South African government has taken a systematic and systemic approach, to address the matter and has developed an approach involving a number of stakeholders from all spheres of government, business, education, civil society and organized labor. That effort led to the e-Skills Summit (2010), which provided the guidelines for the creation of the national e-skills policy named the National e-Skills Plan of Action (NeSPA). This paper, based on descriptive case study methodology, brings a portrayal of that systematic and systemic approach. The paper, aimed at academics, practitioners and policy-makers, also depicts the e-skilling key success factors, expected impact of NeSPA, and the principles for monitoring and evaluation. The paper ends with a brief description of some lessons learned during the initial implementation phase of NeSPA.
\end{abstract}

Keywords: e-skills, national policy, aligning policy, systemic and systematic approach, education, training, developing country, South Africa.

\section{Introduction}

Material published as part of this publication, either on-line or in print, is copyrighted by the Informing Science Institute. Permission to make digital or paper copy of part or all of these works for personal or classroom use is granted without fee provided that the copies are not made or distributed for profit or commercial advantage AND that copies 1) bear this notice in full and 2) give the full citation on the first page. It is permissible to abstract these works so long as credit is given. To copy in all other cases or to republish or to post on a server or to redistribute to lists requires specific permission and payment of a fee. Contact Publisher@InformingScience.org to request redistribution permission.
The establishment and development of the Internet and other information and communication technologies (ICT) in recent decades, represents a material foundation for networked society, often referred to as Information Society or Knowledge Economies - here named as Knowledge Society. Creating such a technology-supported society that can be increasingly self-reliant, socially cohesive and equitable, involves funda- 
mentally new ways of thinking, working and living. It requires the building of new capacities, not only in the work force but the entire population. These capacities are inter alia inevitably associated with the use of ICT and are often referred to as e-skills - comprising knowledge, skills, and competencies, and spans over a number of economic and social dimensions (EESF, 2004; SFIA, 2008). These skills, essential in empowering individuals so that they can participate fully as citizens of the Information Society, broadly refer to the ability to develop and use ICT to adequately participate in an environment increasingly dominated by access to electronically enabled information and a well-developed ability to synthesize this into effective and relevant knowledge (WSIS, 2005). However, these skills are in very short supply across the world generally but in developing nation states in particular. Obtaining appropriate e-skills is not a once-off event since the speed of paradigm technological changes requires that skills need to be continually kept up-todate and relevant. Further, competent currency is often dependent on personal peer-to-peer interactions and on-line support that in itself requires an escalating level of skills. For example, Europe's growing e-skills shortage is affecting the productivity and the competitiveness of large and small organizations across society (eSEW, 2010; eSN, 2010). The situation in South Africa is not much better, causing South Africa (SA) to slip down the international 'e-readiness' rankings - it is estimated that South Africa currently experiences a shortage of over 70,000 IT professionals (ITWeb, 2008). The shortage of e-skills is even more worrying because of the fact that the supply of ICT graduates is now showing a decline (Accenture, 2008; Birchwood Declaration, 2007). This general lack of e-skills is seen by the South African Department of Communications (DoC) as a serious impediment to the Nation meeting its commintment to the Millenium Development Goals (MDGs), the World Summit on Information Society goals (WSIS, 2005), New Partnership for Africa's Development (NEPAD) and the South African Medium Term Strategic Framework 2009-14 (MTSF) (DoC, 2007). Locally, e-skills are seen as vital in addresing poverty, sustainable livelihoods, the fight against crime, building cohesive communities, international cooperation, and building a developmental state (ANOP, 2010).

Although the e-skilling agenda is already being addressed by other, mostly developed, countries (e.g., UK, EU states), the solutions for these countries could not be easily replicated in the South African context as these solutions largely revolve around so called "practitioners" (or professional) e-skills (e.g., SFIA, EESF, 2004) and e-competences (e.g., European e-Competency Framework - EeCF). Unlike South Africa, these countries do not have a need to address, for example, the so called "dual economy", huge social and economic disparities (SA has one of the highest Gini coefficients in the world), massive illiteracy, or considerable "digital divide", which is seen through inequitable access to and ineffective use of the contemporary ICT. Thus, overcoming these serious problems, facing equity and prosperity in South Africa, required a different, substantially proactive and somewhat innovative effort as an increasingly large portion of the population will require effective e-skills for sustainable socio-economic growth and development (NeSPA, 2010). Thus SA government has taken a systemic and systematic approach to e-skilling the nation.

\section{Research Methodology}

Having participated in this process from the inception to the finalization of the National e-Skills Plan of Action (NeSPA, 2010), these authors utilized a case study methodology (Le Compte \& Preissle, 1993:39) to describe a systemic and systematic approach taken and "capture data on the perceptions of local actors from within" (Miles \& Huberman, 1994, p. 6; Leedy, 1997; Yin, 1993) while exploring an event over which the "researcher has little control" (Yin, 2003, p. 5).

The aim of this research was to answer the questions: (i) why an e-skilling agenda in South Africa was needed, (ii) what approach to addressing this agenda was taken and (iii) how it was done (Yin, 1994). The findings are presented here through a "thick description" of the phenomenon under study (Merriam, 1991, p. 11). This paper is, thus, aimed at academics, practitioners and 
policy-makers interested in e-skilling issues. It is particularly aimed at those from developing countries in order to share experience and advance research and practice in this arena.

This paper now proceeds with describing the process establishing e-skills agenda in South Africa, the main actors, and the result of the process: the definition of e-skills in a South African context, key success factors, expected impact and how to monitor and evaluate it, followed by some practical examples of operationalizing NeSPA. This paper ends with a brief reflection and concluding remarks.

\section{The Genesis of e-Skills Agenda in South Africa}

The establishment of the e-skills agenda in South Africa was grounded on a number of assumptions such as the importance of ICT for building Knowledge Society, the evidence of an e-skills shortage in the country (e.g. ITWeb, 2008; Accenture, 2008) and the perceived need for these kinds of skills (NeSPA, 2010). Thus, in order to tackle the problem, the SA government has taken a number of actions such as establishing an e-Skills Institute, organizing the Nation's first e-skills summit and creating the national e-skills Plan of Action (NeSPA).

\section{e-Skills Institute}

In order to create and execute an e-skills agenda in a systemic and systematic manner, the South African government, through the Department of Communications (DoC), established the e-Skills Institute (e-SI). The establishment of e-SI followed the recommendations of the Presidential International Advisory Council (PIAC) in the Information Society and Development (ISAD) Cluster in August 2007 when the shortage of e-skills in South Africa was identified as a serious problem. The seriousness of the problem was recently emphasized by the e-Skills Council that suggested delivering a strategic bridge between the key stakeholders: business, government, education, civil society and organized labor. It is important to notice that all these stakeholders were actively involved in the process of establishing the e-skills agenda in South Africa.

The primary focus of e-SI as a catalytic leader is to engage a wide base of various stakeholders to develop a collaborative and integrated national policy, which should guide further action in " $e$ skilling the nation for more equitable prosperity and global competitiveness” (NeSPA, 2010). The national dialogue for developing an e-skills delivery agenda for South Africa has been achieved through the partnership between e-SI and, for this purpose, its policy and proof of concept agency The Information Society Institute (TISI). This endeavor has culminated in the first South African e-Skills Summit, held in July 2010, which was attended by 300 thought leaders across government (including donor agencies and countries), business (corporate and local), education and civil society (including labor) from across South Africa, continental Africa (Egypt, Mali and Ethiopia) and internationally (Korea, Spain, Australia, United States and Ireland).

\section{e-Skills Summit}

The main purpose of this Summit was to discuss the key matters raised in the draft of the National e-Skills Plan of Action (NeSPA) which was developed as a result of a wide ranging consultative preparatory process named: The Path to the Summit. The draft document, essentially a broad framework, consisted of a compilation of relevant government documents, reports, initiatives and the like - brought together in the initial output of the consultative process. The discussions in the Summit's working groups and panels were, therefore, based on this draft document and revolved around three pillars:

- The context and definition of e-skills within Human Resource Development (HRD) South Africa for socio-economic developmental perspective; 
- Research, evaluation and policy development for e-skills within the context of a developmental state; and

- The alignment of an e-skills effort to the goals of MTSF 2009-14.

The Summit discussions elicited key issues such as (i) the recognition of the high levels of energy and interest across all stakeholder groups for action regarding delivering a collaborative, sustainable and effective national approach to e-skilling, and, (ii) consensus of the importance of addressing the goals of the MTSF (2009-14) through e-Skills enhancement.

It was concluded by the delegates that the e-skilling in South Africa cannot be successful within the old paradigm involving only input (e.g. required resources) and output (e.g. number of eskilled people). The new paradigm, as championed by the e-Skills Summit delegates, required a shift in emphasis from inputs and outputs to impact. It was also recognized that this approach required the development of "collaborative network architecture" through the coordinated effort to shift past "doing to" and/or "doing for" towards "doing with" in dealing with the existing efforts, interests and needs at the local level (e.g. an effort that is seen as "local" in a "community sense"). It was deemed by the delegates that this endeavor requires maximizing the use of existing infrastructure, effort and commitment that would be independent from any direct control of any particular stakeholder but also recognized individual stakeholder inputs and rights. It is believed that this approach could bridge the operational and structural gaps between the stakeholder groups (business, government, education, civil society, organized labor) at local, provincial, national and international levels, thus providing a sustainable national structure.

The Summit ended after three-day long discussions that yielded five overarching themes which were translated into five key recommendations to be completed beyond the Summit (Table 1). The establishment of a regional e-Skills Knowledge Production and Coordination Hubs Network attracted particular attention as the delegates believed that these Hubs "will form the centre piece of these five recommended actions" and will "addresses the key recurring issues of the Summit" as "it goes to the heart of bridging the existing chasms between key stakeholder groups, disciplines, agency programs, output and impact". This initial proposal was aimed "at a government funded pilot process with nine hubs that can establish and develop a model for South Africa in this space which is undoubtedly a high priority need recognized in the highest levels of Governance, Business and Civil Society" (NeSPA, 2010).

Table 1: Summary of the overarching themes, recommendations and stakeholders (based on NeSPA, 2010)

\begin{tabular}{|l|l|l|}
\hline Theme & Recommended Goal & Stakeholder involvement \\
\hline $\begin{array}{l}\text { Shaping NeSPA into a more } \\
\text { comprehensive locally relevant } \\
\text { and impact driven document. }\end{array}$ & $\begin{array}{l}\text { To finalize this working document } \\
\text { before mid-December so that it can } \\
\text { inform the national budget process. }\end{array}$ & $\begin{array}{l}\text { Key representatives from } \\
\text { Government, Higher Educa- } \\
\text { tion, and Civil Society. }\end{array}$ \\
\hline $\begin{array}{l}\text { An ongoing, sustainable and } \\
\text { credible effort to develop an } \\
\text { understanding of the nature } \\
\text { and scope of lifelong abilities } \\
\text { required by South Africans in } \\
\text { the emerging socio-economic } \\
\text { space which will inevitably be } \\
\text { dominated by converging ICT, } \\
\text { needs to be established. }\end{array}$ & $\begin{array}{l}\text { Establish the necessary planning plat- } \\
\text { form for South Africa to better position } \\
\text { itself for providing meaningful work } \\
\text { for its citizens in the emerging Knowl- } \\
\text { edge Society. }\end{array}$ & $\begin{array}{l}\text { Independent research exper- } \\
\text { tise across Universities, Cor- } \\
\text { porates, donor agencies (e.g. } \\
\text { the ResNeS). }\end{array}$ \\
\hline
\end{tabular}




\begin{tabular}{|l|l|l|}
\hline $\begin{array}{l}\text { The establishment of regional } \\
\text { e-Skills Knowledge Centre Net- } \\
\text { work Hubs in collaborative } \\
\text { network architecture. }\end{array}$ & $\begin{array}{l}\text { Establish nine (one per province) e- } \\
\text { Skills Collaborative Knowledge Centre } \\
\text { Network Hubs. }\end{array}$ & $\begin{array}{l}\text { Universities, regional and } \\
\text { local authori- } \\
\text { ties/communities. }\end{array}$ \\
\hline $\begin{array}{l}\text { Developing a differential trans- } \\
\text { fer pricing mechanism to pro- } \\
\text { vide a basic level of free access } \\
\text { to cell phone and internet con- } \\
\text { nectivity. }\end{array}$ & $\begin{array}{l}\text { Develop an implementable approach } \\
\text { either based on similar approaches } \\
\text { used for providing a base level of wa- } \\
\text { ter and electricity to the disadvantaged } \\
\text { and/or a model funded by managed } \\
\text { advertising in models such as those } \\
\text { used by both Google and Skype. }\end{array}$ & $\begin{array}{l}\text { An immediate task of small } \\
\text { team of policy developers } \\
\text { and relevant state owned } \\
\text { enterprise representatives. }\end{array}$ \\
\hline $\begin{array}{l}\text { Development and implementa- } \\
\text { tion of a high priority need for } \\
\text { sectoral e-skilling approaches. }\end{array}$ & $\begin{array}{l}\text { Develop, recommend and implement a } \\
\text { sectoral e-Skills approach. }\end{array}$ & $\begin{array}{l}\text { High level Government Ad- } \\
\text { visory body in conjunction } \\
\text { with national sectoral agen- } \\
\text { cies. }\end{array}$ \\
\hline
\end{tabular}

\section{The Development of NeSPA}

A policy is often described as a purposeful plan of action aimed at guiding decisions and achieving a reasonable outcome by incorporating scientific knowledge into policy. Such a plan of action should be informed by the relevant evidence as linking research, policy and practice that can be helpful especially in the development context (RAPID, 2010). This attitude was needed in order to overcome (or at least alleviate) the challenge that research is being used most frequently to legitimate policy decisions rather than to inform policy formulation processes (Jones et al., 2008). This is particularly true for developing countries as studies show that many policy processes are weakly informed by research-based evidence (Bird et al., 2005). It is often argued that the knowledge gained by research, instead of being used for informing policies, is often isolated from the policy-makers and practitioners in the field. Likewise, tacit knowledge from the field rarely reaches the researchers or those making decisions. Thus, more effective bridges between knowledge, policy and practice are needed (Hearn and White 2009),

Furthermore, e-skills related policies cannot rely on a single framework or a model as there is no such an entity that can be used in all contexts and situations. Thus, it is advisable that policy creation should be based on both: (i) internationally recognized e-skills frameworks, such as SFIA or EeCF, and (ii) on local (SA) research in this area that adds new value (Mitrovic, 2010). In addition, the pertinent literature shows that limited dissemination of research findings can result in systemic obstacles regarding the policy dialogues and decision-making processes (Jones et al., 2009). This was exactly what the e-Skills Summit intended to achieve by means of its two Research Colloquiums (2010 and 2011) at which over 50 e-skills related research papers were presented. These events helped to address the weaknesses of the science-policy interface by facilitating communication (Jones et al., 2009) between researchers, policy-makers and other delegates.

Bearing in mind the above and the fact that the attainment of e- skills should not be sporadic but based on a methodological approach (WSIS, 2003), the compilation of NeSPA was based on:

- policy-making theories,

- internationally recognized e-skills frameworks (e.g. EESF, EeCF);

- local (SA) research, presented through the Research Colloquiums;

- input from the Summit's workshops and panel discussions;

Furthermore, the development of NeSPA was influenced by the e-SI's mandate to support MTSF in relation to the following goals against which monitoring and evaluation will be performed (NeSPA, 2010): 
1. Employment readiness: aimed at the improvement of employment figures for graduates from tertiary institutions and shortened time from employment to productivity. This refers to two aspects of employment readiness: (i) ability to get the job or to start a small business, and (ii) skills to do the work.

2. Effective e-governance and service delivery: aimed at the effective use of ICT for service delivery that is developmental, agile, competent, and citizen-centric. This will result in government having better communication with the people of South Africa, thus focusing service delivery on real needs.

3. Business development: aimed at providing skills needed within corporate, small, medium businesses and micro-enterprises (SMMEs) to: (i) exploit opportunities provided by ICT, notably the Internet and emerging cell phone technologies, (ii) ensure more efficient and effective performance, (iii) explore possibilities for new ways of conducting business and organizational processes, and (iv) establish new businesses.

4. Socio-economic development: aimed at increased national productivity and competitiveness (more competitive workforce), which should inter alia increase the return on ICT investments. The further aim is to increase the uptake of online (e-government) services as well as to support the creation of relevant (local) content by more educated and cohesive citizens.

5. Research and development: aimed at informing policy and curriculum development, defining applications and evaluating progress. The research should be collaboratively useful across government departments and the stakeholders' array and presented in a user friendly, accessible way.

The NeSPA was compiled containing the relevant e-skills definition, the recommendations for action along with key success factors for achieving the delivery, expected impact, and the monitoring and evaluation of the effort. As explained in NeSPA (2010), this national policy is designed to:

- Reflect a national consensus in terms of e-Skills priorities, based on collaborative input from all key Stakeholders (Government, Business, Education, Civil Society/Labor);

- Continuously leverage international benchmarks and good practices (from countries such as Finland, Korea, Australia and the EU) adapted to South Africa's culture and environment, while taking advantage of South - South Cooperation opportunities (including Egypt, Brazil, Cuba, and India);

- Provide a coordinating framework for the effective implementation of current and future e-Skills initiatives matching the developmental, economic and societal needs of South Africa;

- Coordinate existing e-Skills capacity and resources to maximize impact, reduce duplication of effort, and act as a focal point for the development of measureable e-Skills competencies;

- Identify current national and international success stories for adaptation, replication and scaling across South Africa, and share them with the rest of Africa for necessary adaptation, replication and scaling;

- Provide for a framework of relevant coordinated pedagogy development and delivery across the Higher Education Institutions, Sector Education Training Authority (SETA), corporate, and informal e-skills enhancement environment;

- Provide a framework for sharing knowledge based on Provincial and Local "good practices"; 
- Propose fully costed solutions owned by key Stakeholder Groups, to match current and future skills gaps for key sectors identified in the $\mathrm{MTSF}_{2}$ and IPAP2 3 as national priorities;

- Specify performance metrics to facilitate measurement and evaluation of Impact, Return on Investment (ROI) and Return on Objective (ROO) for the NeSPA Implementation Plan;

- Address Political, Economic, Social, Technological, Environmental and Legal (PESTEL) considerations and identify current Public Sector constraints that need to be addressed;

- Prepare an e-Skills requirements map, displaying the skills paths and needs from beginner to expert for MTSF priority areas for economic growth and social development, i.e. sustainable development;

- Define an appropriate "Enabling Environment” in which e-Skills development will thrive; and

- Identify key barriers to success and opportunities for driving synergistic initiatives.

\section{Definition of e-Skills and Emerging e-Skilling Key Success Factors}

\section{E-Skills Definition and NeSPA Taxonomy}

Based on the WSIS (2003) and European e-skills Forum (EESF, 2004) documents, e-SI defines eskills as: “...the ability to develop and use ICTs within the context of a knowledge environment and associated competencies that enable the individual to participate in a world in which ICT is a requirement for advancement in business, government and civil society.” Recognising this complexity, the e-SI initially adopted (in 2008) a taxonomy that describes four types of e-skills (Wesso, 2008):

- ICT practitioner skills: the capabilities required for researching, developing, designing, managing, producing, consulting, marketing, selling, integrating, installing, administrating, maintaining, supporting and servicing ICT systems.

- ICT user skills: the capabilities required for the effective application of ICT systems and devices by the individual.

- $\quad e$-Business skills: the capabilities needed to exploit opportunities provided by ICT - to explore possibilities for new ways of conducting business and organizational processes, and to establish new businesses.

- $\quad e$-Literacy: the capabilities needed to socially appropriate ICT for local development.

This was the point of departure for an extensive discussion about the e-skills definition in the South African context. The above concepts are seen within a broad perspective that encompasses the ability of people to use and create all forms of ICT to improve life opportunities in their personal and educational spaces as well as their work environments, community interactions, and participation in and contribution to (political) governance processes. However, it was believed by the Summit delegates that the above mentioned taxonomy "was limiting", thus requiring reclassification. After an extensive discussion in the dedicated working groups and subsequent plenary debate, new e-skills classification was suggested (NeSPA, 2010):

- e-Literacy Skills: aimed at employment readiness, particularly targeting unemployed and unskilled youth and rural society (including starting own small business); 
- e-Participation and e-Democracy Skills: focusing on enhancing citizen interactive engagement with communities, local, provincial and national governance processes to increase participation, self reliance and equity;

- $\quad$-Government/Governance Skills: focusing on increasing efficiency and productivity interactive bimodal approaches to service delivery of governments and its agencies across all ICT platforms including new cell phone technology, community radio, and the like;

- $\quad e$-Business Skills: aimed at increasing organizational efficiency and productivity;

- $\quad e$-User Skills: focusing on enhancing the efficiency of public and private sector knowledge workers;

- $\quad$-Practitioner Skills: aimed at enhancing the capacity of public and private sectors to manage, support and service ICT; and

- $\quad e$-Community Skills: aimed at increasing self reliance, participation and community support in a socio-economic setting to build social cohesion in ways that can better build local solutions to societal matters such as crime, health, education and the like.

Here it is worth noticing that, although the e-Skills Summit has accepted this new classification, it still has to withstand an academically rigorous examination as this classification (still) does not have a sound theoretical foundation. For example, it is not clear if e-Participation and eDemocracy skills are basically e-Literacy skills applied in a certain context. Also it is not clear if e-Government/Governance skills are distinctive e-skills or merely e-Users and e-Business skills used in the government/governance context.

\section{Key Success Factors for Achieving e-Skills Agenda}

Achieving e-skills goals, as defined in NeSPA (2010), is not an isolated process but is tightly linked to the highest national development policies, such as MTSF 2009-14, or internationally accepted obligations, such as the attainment of MDG. Bearing in mind these facts, the Summit delegates have identified nine key issues for the development of an e-skills action agenda for South Africa. These issues are considered as the key success factors in e-skilling:

- Collaborative approach across existing effort and gaps to action the e-Skills agenda;

- The need for a comprehensive research program that will inform policy development, practice, service delivery and (lifelong) education;

- Action within "A Path to Impact” based approach to enhance the delivery of established policies and programs and build new approaches;

- Cooperative network architecture based on nodes at local level;

- Affordable access to ICT;

- Focus needs to include support for small, micro, and medium enterprises (SMME's)

- Effectively use existing resources;

- Focus on Medium Term Strategic Framework (MTSF) 2009 - 2014; and

- Start the National e-Skills Plan of Action (NeSPA) with a few overarching projects.

\section{Multi-stakeholder partnership}

The collaborative approach to the e-skills agenda primarily means concentration on the multistakeholder partnership projects, which aims to deliver e-skills in a way that would help communities to meet MTSF goals through meeting their local needs. Given that the real needs of local communities mostly require multi-disciplinary and multi-stakeholders involvement, any successful approach will inevitably be based on a collaborative multi-stakeholder partnership. This approach, as believed by the e-Skills Summit delegates, does not only demonstrate the value of their contributions but also provides for the benefit of collaboration that is beyond simple economies of 
scale. This approach should be visible, easily understood by all involved, measurable and capable of making a positive impact in communities, as shown in Figure 1.

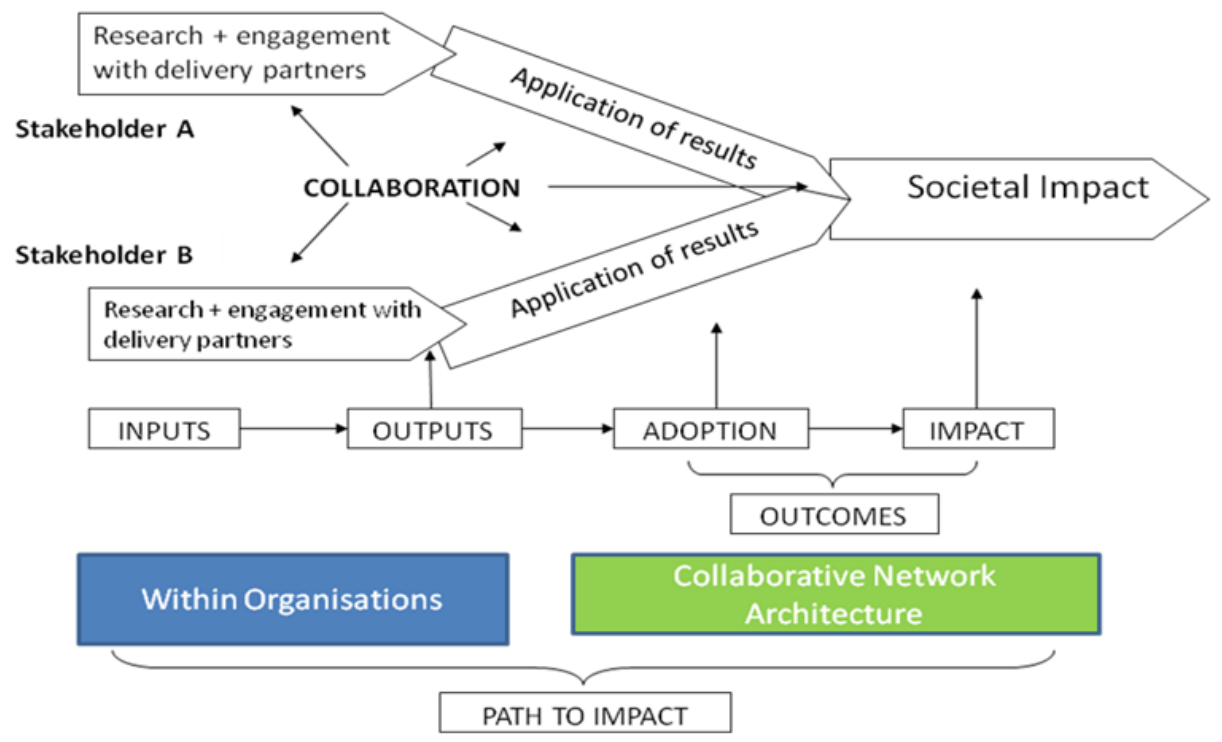

Figure 1: Path of Impact (source: NeSPA, 2010)

\section{Research-based policy development}

Considering the currently unsynchronized e-skills research in South Africa, the delegates of the eSkills Summit suggested that future work needs to be categorized into theme areas that "can allow the assessment of needs and have relevance to the mandate of e-SI, the goals of the MTSF, the discipline base that can support them and the needs of key stakeholder groups" (NeSPA, 2010). Due to the particular South African socio-economic circumstances, the Summit delegates have identified the following policy-making related thematic areas:

- the current e-skills situation in South Africa - including benchmarking and progress against the MTSF goals,

- infrastructure and access - including convergence, new models of access for underserved communities,

- ICT in education - including the alignment of current and future pedagogy aligned to the MTSF,

- ICT in Business - including both the synchronous and asynchronous use of converging technologies in bimodal service delivery, and

- ICT and the community - including the use of social media in meeting the needs of the MTSF.

Within these areas the priority in emerging research should be given to: (i) more equitable access model to infrastructure (ii) needs of the community, (iii) Curriculum development, (iv) Skills gap, and (v) alignment to the MTSF. The measurable and specific milestones, inclusivity in policy development, monitoring and evaluating e-skilling success, tracking the movement of ICT professionals, online availability of education curriculum, and validating e-skills standards are all considered as defining success factors for research-based policy development. The South African Research Network for e-Skills (ResNeS) has recently been established to execute this complex endeavor. 


\section{A path to impact}

The e-skilling activities associated with "A Path to Impact”, as believed by the e-Skills Summit delegates, should be designed in a way that fulfills their expectations, which are generally seen within the development of an all inclusive Knowledge Society in South Africa. That action, performed via a collaborative network architecture, must provide much more than an output that requires "a bold leap of faith" from the action or research project to an identifiable impact. It must be fully and explicitly linked to the highest national developmental policy (MTSF) goals in ways that are visible, traceable and measureable. Translated into concrete recommendations, the following "Big Five” action items were suggested (NeSPA, 2010):

- Completing the NeSPA in ways that build on the collaborative multi-stakeholder processes used thus far.

- Developing a research network that is locally, nationally, continentally and internationally relevant to policy development, service delivery, HRD and socio-economic needs within the context of a development state.

- Establishing the pilot of 9 (one per province) e-Skills Knowledge Centre Network hubs in association with HET Institutions. These pilots need to provide a space for a multistakeholder (Government, Business, Education and Civil Society/Labor) based approach to HRD for Knowledge Societies that can develop equitable prosperity and global competiveness in the emerging dynamic of a developmental state in South Africa.

- Developing a transfer pricing mechanism that provides useful access to the benefits of ICTs across the socio-economic divide such as electricity and water charging policies

- Developing a sectoral approach to e-skilling that not only enhances capacity within the existing labor market but also builds opportunities for efficacy within existing systems and develops new paradigms suited to the needs of the modern world. The experiences of South Korea and the Basque region of Spain provide examples of immediately implementable processes.

The NeSPA particularly advocates the use of an interactive space for action, i.e. the use of an independent physical space for collaboration across government, business, education and civil society within national strategies related to the development of Knowledge Society in South Africa. According to South African and international experience, this is the way to address fundamental socio-economic problems. In this regard, an interesting example was mentioned at the e-Skills Summit (also cited in NeSPA): President Barack Obama recently pointed out that some 20 years ago Kenya (his ancestral African home) had the same GDP as South Korea and that the stark differences between the two countries today are solely dependent upon government focus and commitment to a Knowledge Society approach based on education.

\section{Cooperative architecture}

Despite the aspirations of a number of recent national efforts to address collective national problems through existing delivery channels at national level, the fact remains that, in the absence of a collaborative network architecture that can legitimize development, impact achievement has been less than expected. Since, as deemed by the e-Skills Summit delegates, socio-economic impact is primarily local and then national, addressing the profound issues that South Africa faces in a developmental dynamic can only be found in changing the prevailing paradigm: from "doing to" and "doing for" to "doing with". 


\section{The Dictated Way...Doing to}
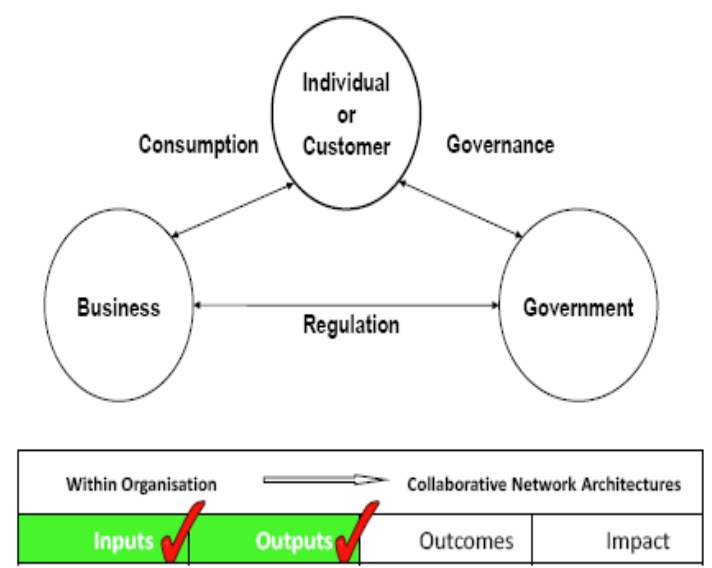

\section{Out Dated Way....Doing For}
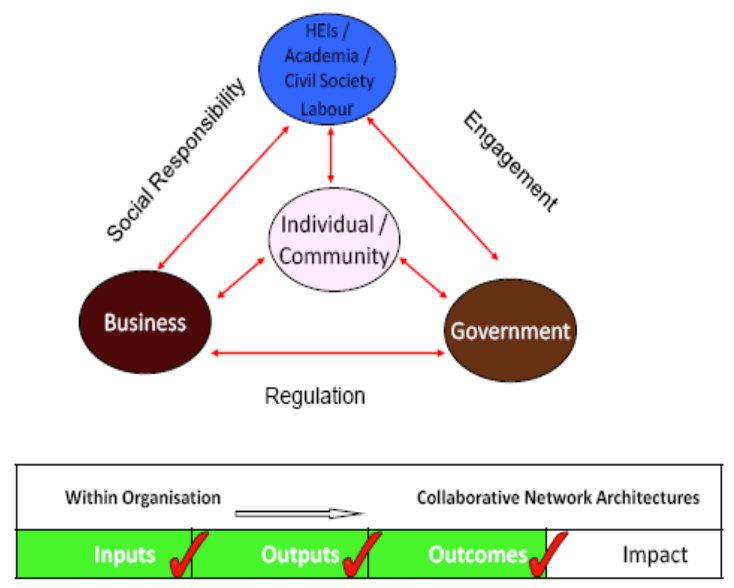

\section{The New Way....Doing with}

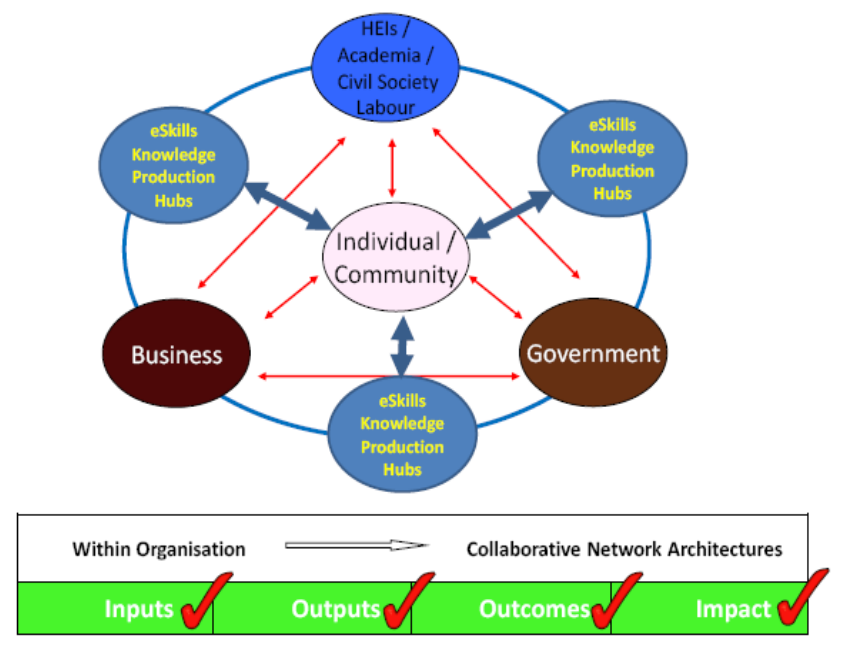

Figure 2: From “Doing To” to “Doing With” (source: NeSPA, 2010)

A “doing with” paradigm requires a new approach based on an independent formalized local collaboration network architecture strongly supported by government. Educational institutions, particularly Higher Education Institutions (HEI), are recognized by the e-Skills Summit delegates as 
having the potential to provide the necessary foundations for these collaborative network architectures. It is envisaged that this new paradigm can be operationalised through the (earlier mentioned) e-Skills Knowledge Centre Network, also referred to as the e-Skills Knowledge Production Hubs.

\section{Affordable access to ICT}

In South Africa, there is recognition that access to affordable and effective ICT is a basic human right. It is believed that, alongside access to water, electricity, transport, food security and right to work, the lack of access to these technologies will rapidly increase inequity (thus negatively impact on social cohesion), reduce effective health care, increase crime, and reduce life opportunities, particularly for the people in poor communities. This affordable access to ICT for all citizens is also a key prerequisite for the sustainable development of e-skills in South Africa. The ubiquitous access to ICT is also seen as the contributing factor towards achieving National Equity Goals (reducing impact of class, race, gender, age, disability, and HIV/AIDS) set out in the National Skills Development Strategy 2011/12 - 2015/16 (NSDS III). As pointed out by the delegates at the e-Skills Summit and stated in NeSPA, delivering equitable access to both ICT and technology based services through a transfer pricing mechanism such as already applies to water and electricity should bring a compelling value proposition, through increased applicability and affordable cost, to all South African people.

\section{Focus on small micro and medium-sized enterprises}

Estimates suggest that within South Africa there are about 2.5 million Small, Medium and MicroEnterprises (SMME), including those in the informal sector. These enterprises constitute up to $95 \%$ of South African businesses. It is further estimated that this sector have doubled in size over the past decade, growing at about 7\% annually (Branam, 2008) and that SMMEs accounts for 99.3\% of all privately owned enterprise in South Africa (PIAC on ISAD, 2007). Not attending to this sector's needs could be detrimental as, for example, "for every [South African] small business that closes ... 6-8 jobs are lost” (Business Times, 13 January 2008, South Africa). Therefore, e-Skills for SMME development bear a very high significance due to the sector's contribution to economic growth and employment.

The high cost of Internet access (particularly in previously disadvantaged and rural areas), lack of integration and coordination of support for SMMEs (small business, in particular), variable service delivery quality (which lowers ability to compete with larger enterprises) late payment patterns by government (increasing financial pressure), and traditional challenges with monitoring and evaluating the SMME sector are the key challenges faced by this sector. Although it is believed that these problems can be addressed by the effective use of ICT, many SMMEs (particularly those from poor and rural areas) are faced with the inability to use these technologies due to insufficient e-Literacy. Thus, the e-Skills Summit delegates deemed that the immediate task was to increase the general level of e-Literacy within this sector. It is believed that this will also help the youth in disadvantaged and rural communities to start their own business. In order to achieve this impact, it is suggested that SMMEs should act in an organized manner in order to have a voice in policy formulation.

\section{Use of existing resources}

One of the key priorities which emerged from the e-Skills Summit was the need for the coordination of existing e-skills capacity and resources to maximize impact, reduce duplication of effort, and act as a focal point for the development of measureable e-skills competencies. Consequently, one of NESPA's objectives is to build a committed national approach for e-skills priorities through coordinated collaboration with key stakeholders (government, businesses, education, civ- 
il society, organized labor) contributing existing human, technical and financial resources. This should be done through the network architecture for cooperation between these stakeholders in order to effectively implement policies, plans and programs for economic development and the optimal use of resources. It is believed that without coordination there is a very high probability of failure and significant waste of resources.

\section{Focus on the national development policies}

The Medium Term Strategic Framework 2009-14 (MTSF) is a national strategy that all public service efforts need to report against. The MTSF lays out 10 issues and 12 impact goals and significant achievements in all of these targets need to involve increased levels of e-skills if they are to be successful and sustainable in the medium to long-term future. As stated in NeSPA, the challenge set out in the MTSF is to find ways to deliver e-skills to communities so that they have a visible impact on the MTSF goals and then to monitor the process in ways that inform continuing effort within the context of a developmental state. For illustration, some of the MTSF strategic priority areas where a coordinated e-skills agenda can initially play a significant role are summarized in Table 2.

Table 2: MTSF strategic and e-skills priorities (based on NeSPA, 2010)

\begin{tabular}{|c|c|}
\hline MTSF Strategic Priority & MTSF e-Skills Strategic Priority \\
\hline $\begin{array}{l}\text { Speeding up growth and transforming the } \\
\text { economy to create decent work and sustainable } \\
\text { livelihoods }\end{array}$ & $\begin{array}{l}\text { - e-Skills development interventions for creating a } \\
\text { more inclusive Knowledge Society } \\
\text { - Strengthening competitiveness and promotion of } \\
\text { SMMEs (e-Business Skills) } \\
\text { - Ensure that the delivery of e-skills keeps up with } \\
\text { global technological trends }\end{array}$ \\
\hline $\begin{array}{l}\text { Comprehensive development strategy linked to } \\
\text { land and agrarian reform and food security by: } \\
\text { (i) improving service delivery to ensure } \\
\text { quality of life by providing e-Skills for } \\
\text { the use of appropriate ICTs to overcome } \\
\text { physical and other impediments, and } \\
\text { (ii) Developing appropriate e-skills train- } \\
\text { ing programmes to support rural econo- } \\
\text { mies. }\end{array}$ & $\begin{array}{l}\text { Address the current e-skills gaps, initiatives focused on } \\
\text { rural development, overcoming geographic isolation, } \\
\text { food security, land and agrarian reform at national, pro- } \\
\text { vincial and local levels. }\end{array}$ \\
\hline $\begin{array}{l}\text { Strengthen the skills and human resource base } \\
\text { by ensuring that training and skills develop- } \\
\text { ment initiatives in the ICT domain respond to } \\
\text { the requirements of the economy, rural devel- } \\
\text { opment challenges and social integration }\end{array}$ & $\begin{array}{l}\text { Address the current e-skills gaps and initiatives at na- } \\
\text { tional, provincial, local and sectoral levels: } \\
\text { - e-skills and lead sectors, focus areas and longer } \\
\text { term potential areas identified in MTSF, and } \\
\text { Tracking international e-skills related initiatives } \\
\text { (e.g. Brazil, Cuba, Finland, India, Ireland, Korea, } \\
\text { Russia, EU, Malaysia, and Australia). }\end{array}$ \\
\hline $\begin{array}{l}\text { Building cohesive caring and sustainable } \\
\text { communities }\end{array}$ & $\begin{array}{l}\text { Through the delivery of e-skills for development, expand } \\
\text { opportunities for the poor to access the labor market (e- } \\
\text { Skills } 4 \text { Dev). }\end{array}$ \\
\hline
\end{tabular}




\section{The Impact, Monitoring, and Evaluation}

\section{Expected Impact}

The expected impact of addressing the e-Skills agenda in South Africa in a systemic and systematic manner is tightly related to MTSF through: (i) NeSPA areas of impact (e-Literacy Skills, $e$ Participation and e-Democracy Skills, e-Government/Governance Skills, e-Business Skills, $e$ User Skills, $e$-Practitioner Skills, $e$-Community Skills) and (ii) the $e$-SI mandated goals (employment readiness, effective e-governance and service delivery, business development, socioeconomic development, research and development). In general, the expected impact should be seen through the development of a more inclusive Knowledge Society in South Africa. The expected impact on the socio-economic development, as seen through benefits (Table 3), range from increasing national productivity and global competitiveness, proposals and solutions to socio-economic matters as well as increased social cohesion that can strengthen technology based and community based approaches to socio-economic development.

Table 3: Mapping impact of e-Skills against NeSPA goals (source: NeSPA, 2010)

\begin{tabular}{|c|c|c|c|c|c|c|c|}
\hline \multicolumn{7}{|c|}{ NeSPA areas of impact } & \multirow[b]{2}{*}{$\begin{array}{l}e- \\
\text { Community } \\
\text { Skills }\end{array}$} \\
\hline $\begin{array}{l}\text { NeSPA } \\
\text { goals }\end{array}$ & e-Literacy & $\begin{array}{l}\begin{array}{l}e- \\
\text { Participation } \\
\text { and }\end{array} \\
\text { e-Democracy } \\
\text { Skills }\end{array}$ & $\begin{array}{l}\text { e- } \\
\text { Government/ } \\
\text { Governance } \\
\text { Skills }\end{array}$ & $\begin{array}{l}\text { e-Business } \\
\text { Skills }\end{array}$ & $e$-User Skills & $\begin{array}{l}\text { e- } \\
\text { Practitioner } \\
\text { Skills }\end{array}$ & \\
\hline $\begin{array}{l}\text { Employment } \\
\text { readiness }\end{array}$ & $\begin{array}{l}\text { - Improved } \\
\text { chances for } \\
\text { obtaining job. } \\
\text { - Improved } \\
\text { efficiency in } \\
\text { the workplace } \\
\text { and hence cost } \\
\text { saving. }\end{array}$ & $\begin{array}{l}\text { - Increased } \\
\text { national pro- } \\
\text { ductivity and } \\
\text { competitive- } \\
\text { ness - more } \\
\text { competitive } \\
\text { workforce. }\end{array}$ & $\begin{array}{l}\text { - Growth in } \\
\text { SMMEs, } \\
\text { leading to } \\
\text { improved } \\
\text { employment } \\
\text { and productiv- } \\
\text { ity. }\end{array}$ & $\begin{array}{l}\text { - Greatly } \\
\text { improved } \\
\text { efficiency } \\
\text { levels and } \\
\text { faster delivery. } \\
\text { - More em- } \\
\text { powered em- } \\
\text { ployees. }\end{array}$ & $\begin{array}{l}\text { - Better in- } \\
\text { formed profes- } \\
\text { sionals who are } \\
\text { aware of lead- } \\
\text { ing trends and } \\
\text { thinking. } \\
\text { - Increase in } \\
\text { speed and } \\
\text { quality of } \\
\text { decision. }\end{array}$ & $\begin{array}{l}\text { - Appropriately } \\
\text { benchmarked } \\
\text { qualification } \\
\text { influences } \\
\text { greater collabo- } \\
\text { ration on } \\
\text { employee } \\
\text { development } \\
\text { programmes in } \\
\text { the work place, } \\
\text { thus influenc- } \\
\text { ing. } \\
\text { - Greater } \\
\text { willingness of } \\
\text { employ to } \\
\text { remain in } \\
\text { company. }\end{array}$ & $\begin{array}{l}\text { - Higher level } \\
\text { of expectation } \\
\text { at the commu- } \\
\text { nity level. } \\
\text { - Increased } \\
\text { levels of e- } \\
\text { skills in the } \\
\text { community will } \\
\text { provide a more } \\
\text { embedded } \\
\text { access to } \\
\text { support for } \\
\text { young and old } \\
\text { learners. } \\
\text { - Remove the } \\
\text { "unknown" }\end{array}$ \\
\hline $\begin{array}{l}\text { Effective e- } \\
\text { governance } \\
\text { and service } \\
\text { delivery }\end{array}$ & $\begin{array}{l}\text { - Increased } \\
\text { productivity. } \\
\text { - Better HR } \\
\text { wellness. } \\
\text { - Less waste, } \\
\text { less duplication } \\
\text { of effort. }\end{array}$ & $\begin{array}{l}\text { - More open, } \\
\text { flexible and } \\
\text { collaborative } \\
\text { government in } \\
\text { their delivery } \\
\text { of public } \\
\text { services. } \\
\text { - Increases the } \\
\text { uptake of } \\
\text { online services } \\
\text { which im- } \\
\text { proves access } \\
\text { to e- } \\
\text { Government } \\
\text { services }\end{array}$ & $\begin{array}{l}\text { - Effective and } \\
\text { accountable } \\
\text { service delivery } \\
\text { - More em- } \\
\text { powered em- } \\
\text { ployees creat- } \\
\text { ing champions } \\
\text { and knowledge } \\
\text { workers } \\
\text { - Reduction of } \\
\text { wastage of } \\
\text { resources }\end{array}$ & $\begin{array}{l}\text { - Improved } \\
\text { collaboration } \\
\text { between busi- } \\
\text { ness and gov- } \\
\text { ernment will } \\
\text { result in creat- } \\
\text { ing sustainable } \\
\text { cost effective } \\
\text { innovative } \\
\text { solutions }\end{array}$ & $\begin{array}{l}\text { - High levels of } \\
\text { participation } \\
\text { and collabora- } \\
\text { tion within and } \\
\text { between gov- } \\
\text { ernment de- } \\
\text { partments and } \\
\text { agencies. }\end{array}$ & $\begin{array}{l}\text { - Improved } \\
\text { service delivery } \\
\text { - Improved use } \\
\text { of technology } \\
\text { that will trans- } \\
\text { late into better } \\
\text { service delivery }\end{array}$ & $\begin{array}{l}\text { - Improved } \\
\text { community } \\
\text { acceptance of } \\
\text { the benefits of } \\
\text { embedded use } \\
\text { of ICT in } \\
\text { service delivery } \\
\text { and improved } \\
\text { bimodal inter- } \\
\text { actions. } \\
\text { - Improved } \\
\text { capacity to help } \\
\text { shape more } \\
\text { effective ser- } \\
\text { vice delivery } \\
\text { models }\end{array}$ \\
\hline
\end{tabular}




\begin{tabular}{|c|c|c|c|c|c|c|c|}
\hline $\begin{array}{l}\text { Business } \\
\text { development }\end{array}$ & $\begin{array}{l}\text { - Increased } \\
\text { productivity. } \\
\text { - Better HR } \\
\text { wellness. } \\
\text { - More busi- } \\
\text { ness opportuni- } \\
\text { ties. }\end{array}$ & $\begin{array}{l}\text { - Networked } \\
\text { community and } \\
\text { business in- } \\
\text { creases both } \\
\text { community and } \\
\text { business sus- } \\
\text { tainability. }\end{array}$ & $\begin{array}{l}\text { - Businesses } \\
\text { could be em- } \\
\text { powered by e- } \\
\text { government } \\
\text { services de- } \\
\text { signed around } \\
\text { their needs }\end{array}$ & $\begin{array}{l}\text { - Increases } \\
\text { national pro- } \\
\text { ductivity and } \\
\text { competitive- } \\
\text { ness in the } \\
\text { global market } \\
\text { - Increase in } \\
\text { return on } \\
\text { investment in } \\
\text { ICT infrastruc- } \\
\text { ture. }\end{array}$ & $\begin{array}{l}\text { - Skilled work- } \\
\text { ers, improve } \\
\text { service delivery } \\
\text { and productiv- } \\
\text { ity. }\end{array}$ & $\begin{array}{l}\text { - Employers } \\
\text { should be } \\
\text { assured that the } \\
\text { degree/diploma } \\
\text { comes with } \\
\text { known skills } \\
\text { and hence cost } \\
\text { of employment } \\
\text { would be } \\
\text { reduced } \\
\text { - Improved } \\
\text { ability to } \\
\text { impact on } \\
\text { business } \\
\text { growth, stay } \\
\text { abreast in } \\
\text { global econ- } \\
\text { omy. }\end{array}$ & $\begin{array}{l}\text { - Better com- } \\
\text { munity under- } \\
\text { standing of the } \\
\text { reality of e- } \\
\text { enabled busi- } \\
\text { ness develop- } \\
\text { ment. } \\
\text { - Improved } \\
\text { understanding } \\
\text { of how to } \\
\text { support emerg- } \\
\text { ing businesses } \\
\text { through online } \\
\text { activities }\end{array}$ \\
\hline $\begin{array}{l}\text { Socio- } \\
\text { economic } \\
\text { development }\end{array}$ & $\begin{array}{l}\text { - Better self- } \\
\text { awareness } \\
\text { - Participate in } \\
\text { knowledge } \\
\text { economy. } \\
\text { - Access to } \\
\text { services and } \\
\text { knowledge to } \\
\text { improve levels } \\
\text { of development } \\
\text { and breaking } \\
\text { the cycle of } \\
\text { poverty. } \\
\text { - Ability to } \\
\text { remain in the } \\
\text { rural commu- } \\
\text { nity and still do } \\
\text { meaningful and } \\
\text { rewarding } \\
\text { work. }\end{array}$ & $\begin{array}{l}\text { - More edu- } \\
\text { cated commu- } \\
\text { nity members } \\
\text { who engage } \\
\text { with the politi- } \\
\text { cians and } \\
\text { political proc- } \\
\text { ess introducing } \\
\text { accountability } \\
\text { into service } \\
\text { delivery. } \\
\text { - Networked } \\
\text { community } \\
\text { increases social } \\
\text { cohesion. }\end{array}$ & $\begin{array}{l}\text { - Citizens could } \\
\text { be empowered } \\
\text { by e- } \\
\text { government } \\
\text { services de- } \\
\text { signed around } \\
\text { users' needs } \\
\text { (citizen-centric } \\
\text { applications } \\
\text { and solutions) } \\
\text { - Increased } \\
\text { access to public } \\
\text { information, } \\
\text { strengthened } \\
\text { transparency } \\
\text { and effective } \\
\text { means for } \\
\text { involvement of } \\
\text { stakeholders in } \\
\text { the policy } \\
\text { process. }\end{array}$ & $\begin{array}{l}\text { - Growth in } \\
\text { SMMEs, } \\
\text { leading to } \\
\text { improved } \\
\text { employment } \\
\text { and productiv- } \\
\text { ity. } \\
\text { - If this is } \\
\text { coupled with e- } \\
\text { literate society } \\
\text { it will also lead } \\
\text { to improved } \\
\text { engagement } \\
\text { and improved } \\
\text { ownership on } \\
\text { the part of the } \\
\text { Government } \\
\text { employer since } \\
\text { progress can be } \\
\text { tracked. }\end{array}$ & $\begin{array}{l}\text { - An informed } \\
\text { society as } \\
\text { knowledge is } \\
\text { easily accessi- } \\
\text { ble to the } \\
\text { various groups } \\
\text { who need it. } \\
\text { - Achieving the } \\
\text { proposed goal: } \\
\text { "e-Skills for } \\
\text { All". }\end{array}$ & $\begin{array}{l}\text { - Developing of } \\
\text { cutting-edge } \\
\text { technology } \\
\text { solutions for } \\
\text { the African } \\
\text { context. } \\
\text { - Contributing } \\
\text { to South Afri- } \\
\text { can global } \\
\text { competitive- } \\
\text { ness. }\end{array}$ & $\begin{array}{l}\text { - Improved } \\
\text { community } \\
\text { capacity to } \\
\text { develop and } \\
\text { articulate } \\
\text { needs, propos- } \\
\text { als and solu- } \\
\text { tions to socio- } \\
\text { economic } \\
\text { matters. } \\
\text { - Improved } \\
\text { social cohesion } \\
\text { that can } \\
\text { strengthen } \\
\text { technology } \\
\text { based and } \\
\text { community } \\
\text { based ap- } \\
\text { proaches to } \\
\text { socio-economic } \\
\text { development }\end{array}$ \\
\hline $\begin{array}{l}\text { Research } \\
\text { and devel- } \\
\text { opment }\end{array}$ & $\begin{array}{l}\text { - finding ways } \\
\text { for an effective } \\
\text { obtainment and } \\
\text { application of } \\
\text { e-literacy } \\
\text { skills. }\end{array}$ & $\begin{array}{l}\text { - Understand- } \\
\text { ing the ways of } \\
\text { better coordina- } \\
\text { tion and inte- } \\
\text { gration be- } \\
\text { tween e- } \\
\text { skilling role- } \\
\text { players. }\end{array}$ & $\begin{array}{l}\text { - innovative } \\
\text { use of ICT to } \\
\text { drive more } \\
\text { effective e- } \\
\text { government } \\
\text { services and } \\
\text { delivery } \\
\text { - A repository } \\
\text { or knowledge } \\
\text { portal of ICT } \\
\text { solutions, tools, } \\
\text { case studies. }\end{array}$ & $\begin{array}{l}\text { - Teaching and } \\
\text { learning new } \\
\text { skills to inte- } \\
\text { grate in cur- } \\
\text { riculum design. } \\
\text { - Innovative } \\
\text { use of ICT for } \\
\text { sustainability } \\
\text { (e.g. Triple } \\
\text { Bottom Line). }\end{array}$ & $\begin{array}{l}\text { - Explore } \\
\text { effective use of } \\
\text { e-User skills in } \\
\text { context in } \\
\text { which they will } \\
\text { be applied and } \\
\text { minimum } \\
\text { standards for } \\
\text { progression on } \\
\text { the skills } \\
\text { ladder. }\end{array}$ & $\begin{array}{l}\text { - Intelligent } \\
\text { and useful } \\
\text { proposals for } \\
\text { innovative and } \\
\text { sustainable use } \\
\text { of ICT. }\end{array}$ & $\begin{array}{l}\text { - Improved } \\
\text { community } \\
\text { capacity to } \\
\text { understand } \\
\text { research needs, } \\
\text { capacity and } \\
\text { focus to deliver } \\
\text { useful out- } \\
\text { comes and } \\
\text { impact in } \\
\text { community. } \\
\text { - Improved } \\
\text { capacity to } \\
\text { identify re- } \\
\text { search oppor- } \\
\text { tunities and } \\
\text { participate in } \\
\text { design, data } \\
\text { collection and } \\
\text { analysis. }\end{array}$ \\
\hline
\end{tabular}

\section{Monitoring and Evaluation}

The monitoring and evaluation, through the NeSPA envisaged e-skilling impact, should be based on three pillars:

- The Human Resource Planning Strategic Framework (DPSA, 2009 [p33]) definition that sees monitoring as "a routine on-going assessment of activities, applied to assess inputs in a project in terms of outputs and outcomes" and evaluation as "an assessment of the impact the project had on the attainment of organizational objectives, performed during the evaluation period", and 
- Some of the key elements specified in the South African President's 2010 State of the Nation Address (Joint Sitting of Parliament, Cape Town, 11 February 2010): "We are building a performance-oriented state, by improving planning as well as performance monitoring and evaluation. The work of departments will be measured by outcomes, developed through our performance monitoring and evaluation system. The Ministers, who are responsible for a particular outcome, will sign a detailed delivery agreement with the President. It will outline what is to be done, how, by whom, within what time period and using what measurements and resources".

- National auditing of e-Skills (across the frameworks outlined in NeSPA) on an annual basis should be a matter of compliance.

As stated in NeSPA, it will be the responsibility of the e-Skills Institute to provide a monitoring and evaluation coordination function in a coordinated manner and to involve all relevant government departments in this process. In the manner that Ministers have signed agreements with the President to deliver on MTSF goals, Departmental senior management will also have agreements with their Ministers to support this endeavor. However, in order to address real community needs through multi-stakeholder based e-skills projects, local ownership of the implementation, evaluation and the monitoring is required. It is crucial to involve all stakeholders in ways that adequately assist in bringing their outputs and outcomes into an impact based evaluation within the goals of the MTSF.

It is advised that the development and delivery of NeSPA projects should be commenced by establishing baseline criteria clearly aligned to MTSF and e-SI goals, which can be continuously evaluated in ways that inform all stakeholders of progress and options for modifications. The establishment of the regional coordinated e-Skills Knowledge Production Hubs and engagement of all relevant stakeholders is seen as crucial for effective monitoring and evaluation of the e-skilling effort in South Africa. Furthermore, monitoring and evaluation should be modeled according to the widely accepted indexes, for example: ICT Development Index (IDI), Knowledge Economy Indicator (KEI) or e-Readiness Index. However, aligning performance against these indices should not prevent developing new appropriate indices that would be more relevant to the needs of a developmental state.

\section{Early Operationalization of NeSPA: e-Skilling Managers of the Community e-Centers}

In order to test conceivability of the e-skilling guidelines stipulated by NeSPA, the pilot project aimed at e-skilling a number of managers of the community e-Centers was accordingly planed and delivered. It was envisaged that these managers will act as catalysts in e-skilling the local communities they belong to. To illustrate some lessons learned from this pilot project, this section provides a very brief feedback on a number of training sessions for 18 managers coming from 10 community e-Centers: three urban, three peri-urban and four rural. The sessions held in April and October 2011 were conducted by the Western Cape e-Skills Knowledge Production and Coordination Hub, managed by the University of the Western Cape. This Hub is mandated to provide eskills for digital Inclusion (DI). The pilot project in that regard aimed at providing e-Literacy to the participating e-Centers managers.

The participants came with very diverse educational and cultural backgrounds which imposed a significant challenge for an effective delivery of the program. Majority of them have accomplished only high school with only one having undergraduate and one postgraduate degree. Roughly, one third of them were speaking English, one third Afrikaans and the remaining third Xhosa. The program was delivered in three phases deploying the face-to-face and online interac- 
tions. The first phase allowed for the socialization and familiarization of the participants with the online and off-line modes of delivery as well as various e-tools (e.g. email software, web browsers, open source picture editing tools and alike). The second phase entailed the integration of the design of an intensive online facilitation support encompassing an in-depth planning, coordination and facilitation of interactive, substantive online discussion topics, creation of assessment tasks related to the selected e-Centre management content and the learning material. The third phase entailed the integration of the design and practice of the first two phases of the training, leading to the certification of the participants.

The expectations of the participants were also diverse: from learning more about MS PowerPoint and MS Outlook to learning how to manage an e-learning center efficiently or how to become more creative and confident in working with other people. In doing this e-skills program the Hub staff have learned what skills and knowledge were the most important to the community e-Centre managers: interpersonal skills, ICT skills, administrative skills, community interaction skills, management skills and so forth. This allowed the e-skills curriculum development team to refine it for the future courses.

In order to evaluate thus far delivered courses and learn valuable lessons, the participants were asked to answer the questions: (i) what was good about the presenters and presentations, (ii) how the presenters and presentations can improve, (iii) usefulness of the course content, (iv) recommendations to improve the content and the presentations, (v) the value of the group presentation and how these kinds of presentations can improve. In general, the participants have agreed that the presentations were very useful and the presenters were well prepared and willing to help. However, the main suggestion for the improvement of the presentations came from the participants with the first language other than English (the language of the course). This yet again confirmed importance of localizing the content into the indigenous languages. Although the course content helped the participants to acquire very useful knowledge and skills, they expressed their desire to be trained in their native language "to serve community better", as one of the participants remarked.

The course feedback was overall positive. Such a positive feedback on the group activities is shown in the graph in Figure 3:

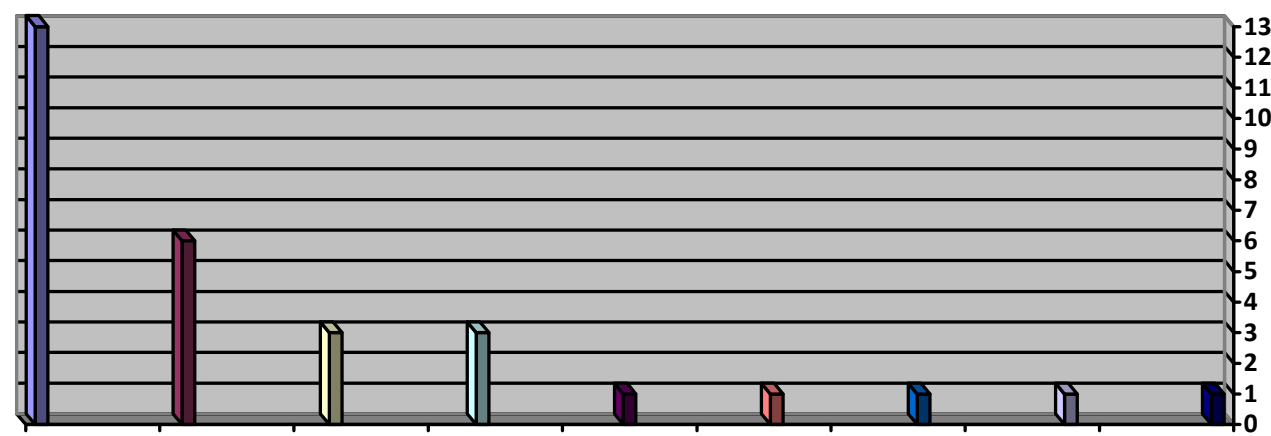

\begin{tabular}{|lll|}
\hline$\square$ Sharing knowledge & $\square$ Collaborating & $\square$ Use of software \\
$\square$ Learning from others & $\square$ Having fun & $\square$ Being creative \\
$\square$ Making friends & $\square$ Practical skills & $\square$ Generally positive \\
\hline
\end{tabular}

Figure 3: Positive feedback on e-skilling group activities 
However, there is always room for improvement. To improve the group interaction and presentations, for example, the participant suggested more interaction within the group, increased facilitation of discussion and debates and providing more study material.

To conclude this section, this pilot project has shown that the NeSPA guidelines are operationalizable thou the curriculum for the future courses must be refined in accordance with the experience gained at the presentations reported here. In fact, this pilot project suggests that the operationalization of NeSPA should be the context dependent (e.g., language, local socio-economic needs). However, the final evaluation if the courses provided by the Western Cape e-Skills Knowledge Production and Coordination Hub will provide more precise guidelines for the future DI curriculum development.

\section{Conclusion}

The objective of this study was to describe a systemic and systematic approach to addressing the e-skills agenda in specific context of a developing country such as South Africa. This research, based on a descriptive case study methodology, tried to answer the question (i) why the e-skilling agenda in South Africa was needed, (ii) what approach to addressing this agenda was taken and (iii) how it was done. This paper portrayed a process of creation of the highest national e-skills policy: from its inception to the compilation of the National e-Skills Plan of Action. This process (Figure 4) required a proactive and somewhat innovative effort due to the unique South African circumstances: "dual economy", huge social and economical disparities, massive illiteracy, and considerable "digital divide", seen through inequitable access to and effective use of the contemporary ICT. The complexity of issues to be addressed, caused by the uniqueness of local context and still insufficiently developed e-skills frameworks (almost non-existent in the context of developing countries), required both a systemic and systematic approach.

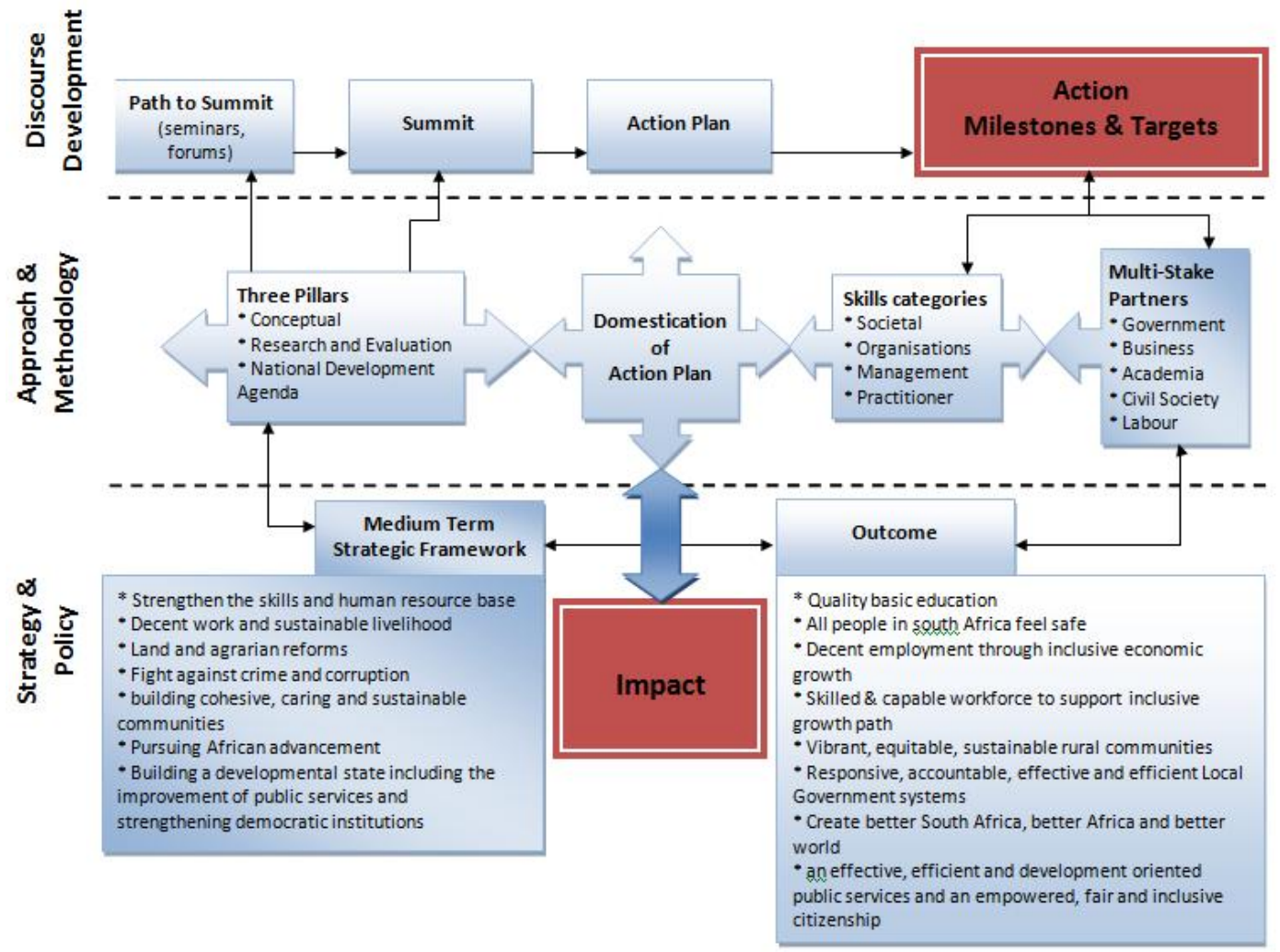

Figure 4: Towards NeSPA (source: NeSPA, 2010) 
The systematic approach was achieved by involving a broad base of stakeholders that included all levels of government (national, provincial, and local), business (corporate and SMME), education (all levels), civil society (Non Government Organizations -NGOs, Not for Profit Organizations NFPs, Community-based Organizations - CBOs) and organized labor. This systematic approach is also characterized by an extensive collaborative process of addressing the e-skills agenda over a period of 18 months before and during the e-Skills Summit, held in Cape Town in July 2010.

The systemic approach to " $e$-Skilling the Nation" (NeSPA, 2010) was prompted by inefficiency and ineffectiveness of "in-silo" and sporadic e-skilling actions taken by various stakeholders in the last decade. The current involvement of many stakeholders and the linking of the e-skills agenda to other national (e.g. MTSF) and international (e.g. MDG, WSIS) programs and policies gives the National e-Skills Plan of Action systemic character.

This collectively owned NeSPA that explains setting and achieving goals, the key success factors, expected impact, and the principles for monitoring and evaluation is based on three pillars that require further progression:

- an advanced understanding of the breadth and depth of e-skills,

- research needed to develop their real-life application and apply these experiences to policy development, and

- their relevance to South Africa's strategic direction;

In this regard, the pilot project, conducted at the Western Cape e-Skills Knowledge and Coordination Hub, provided valuable input to both policy creation and execution at the "cellular" community level.

As a "living document", NeSPA will rely on continuous monitoring and evaluation of the national and international environment in order to address the constantly changing challenges of the impact of exponentially converging ICT. It is now to academics, practitioners and policy-makers to assess the appropriateness of this e-skilling approach and to suggest possible modifications. The experience gained through the process of addressing the e-skills agenda in South Africa and the creation of NeSPA might also be useful for addressing this agenda in other developing countries.

\section{References}

Accenture. (2008). The ICT skills landscape of South Africa: A viewpoint on demand, supply and applicable international benchmarks. Prepared by Accenture for the South African e - Skills Working Group, August 2008.

ANOP. (2010). Advanced notice and opportunity to participate: e-Skills Summit South Africa -2101. Department of Communications (DoC), South Africa, September 2009.

Birchwood Declaration. (2007). Tertiary level ICT skills development. Retrieved 2 June 2008, from: www.cs.ru.ac.za/ ICTSkills/Declaration\%20ICT-Skills\%202007.pdf

Bird, K., \& Pratt, N., with T. O’Neil \& V. Bolt (2004). Fracture points in social policies for chronic poverty reduction. ODI Working Paper 242. London: ODI.

Branam, C. (2008). The South African small business environment. July 2008, Occasional Paper 25.

DPSA. (2009). Human resource planning (HRP) for the public service: Strategic framework vision 2015. Department of Public Service and Administration, RSA.

DoC. (2007). Towards a strategic framework for ICT skills development in South Africa. Report by Department of Communication (DoC), 2007.

EESF. (2004). The European e-skills forum e-skills for Europe: Towards 2010 and beyond. The European e-skills forum, Synthesis Report, September 2004. 
eSEW. (2010). e-Skills: European Week 2010 underlines e-skills' potential to help Europe's economic recovery. Brussels, 2010. Retrieved from http://europa.eu/rapid/pressReleasesAction.do?reference=IP/10/220\&format=HTML\&aged=0\&langua ge=EN\&guiLanguage $=$ en

eSN (e-skills News). (2010). The e-skills Manifesto - Employers call for action on e-skills. Retrieved 01 Mar 2010, from http://www.e-skills.com/cgi-bin/go.pl/newscentre/news/news.html?uid=1067

Hearn, S., \& White, N. (2009). Communities of practice: Linking knowledge, policy and practice. Retrieved 12 February 2010, from http://www.odi.org.uk/resources/download/1129.pdf

ITWeb. (2008). ITWeb -JCSE ICT skills survey. Released in September 2008 on a DVD as a Power Point presentation with accompanying audio.

Jones, N., Jones, H., \& Walsh, C. (2008). Political science? Strengthening science-Policy dialogue in developing countries. Working Paper 294. London: ODI.

Jones, N., Walker, D., \& Walsh, C. (2009). Strengthening science-Policy dialogue in developing countries: A priority for climate change adaptation. Background Note. December 2009.Overseas Development Institute.

Le Compte, M. D., \& Preissle, J. (1993). Ethnography and qualitative design in educational research. (2nd ed.). New York: Academic Press.

Leedy, P. D. (1997). Practical research: Planning and design (6th ed.). Upper Saddle River, NJ: Prentice Hall.

Merriam, S. B. (1991). Case study research in education: A qualitative approach. San Francisco: JosseyBass.

Miles, M. B., \& Huberman, A. M. (1994). Qualitative data analysis. London: Sage.

Mitrovic, Z. (2010). Positioning e-Skills within an organisation: Policy making implications. e-Skills Summit 2010 Proceedings, Paul Cunningham and Miriam Cunningham (Eds)IIMC International Information Management Corporation, 2010.

NeSPA. (2010).The national e-Skills plan of action. The Department of Communication, South Africa. Retieved on 24 October 2010 from www.doc.gov.za

PNC ISAD. (2007). Information Society and Development (ISAD) Plan. Presidential National Commission on Information Society and Development. Retrieved 23 November 2008, from http://www.pnc.gov.za/emzanzi_issue1_07/

RAPID -The Research and Policy in Development. (2010). Retrieved 7 May 2010, from http://www.odi.org.uk/programmes/rapid/

SFIA - Skills Framework for the Information Age. (2008). Framework reference SFIA version 4. London: SFIA Foundation.

Wesso, H. (2008). e-Skills: Building the information society and knowledge economy. Work in progress, Dr Harold M Wesso, Acting CEO: Meraka e-Skills Institute, Department of Communications, 30 January 2008. Retrieved 15 February 2009, from http://196.30.226.221/events/ictskills/presentation/harold_wesso.pps

WSIS. (2003).World summit on the information society. Document WSIS-03/GENEVA/DOC/4-E”, 12 December 2003

WSIS. (2005).World Summit on the Information Society. Tunis e-Skills Report. Tunis

Yin, R. (1993). Applications of case study research. Newbury Park, CA: Sage Publishing.

Yin, R. K. (1994). Case study research, design and methods. Thousand Oaks: SAGE Publications.

Yin, K. (2003). Case study research: Design and methods (3rd ed.). Thousand Oaks, CA: Sage Publications. 


\section{Biographies}

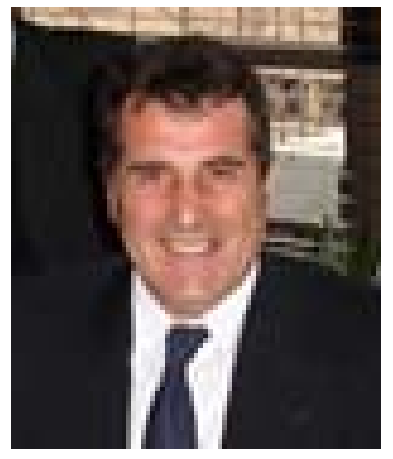

Dr Zoran Mitrovic is the Coordinator of the Masters in Information Management Programme at the University of the Western Cape, South Africa and Managing Director of the Mitrovic Development Institute. He is one of the authors of the South African National e-Skills Plan of Action (Department of Communications). His research and praxis encompasses the development of e-skills in the developmental context, the use of ICT for local socio-economic development, e-government strategies, policies and implementation, and the use of ICT for environmentally sustainable development. He has been awarded for his research work.

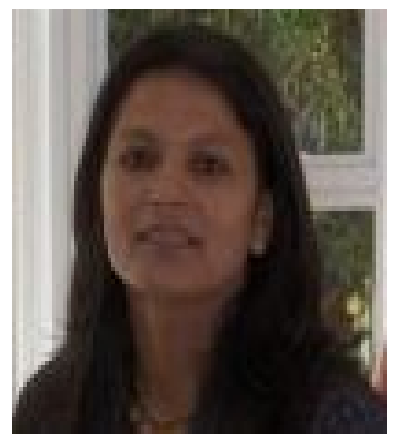

Mymoena Sharinf is an official of the Department of Communications e-Skills Institute, a South African government initiative to advance and implement key e-skills interventions. She is a member of the Strategic Council for the United Nations Global Alliance on ICT for Development and is a former winner of the Bill \& Melinda Gates International Access to Learning Award. She is co-author of the South African National e-Skills Plan of Action.

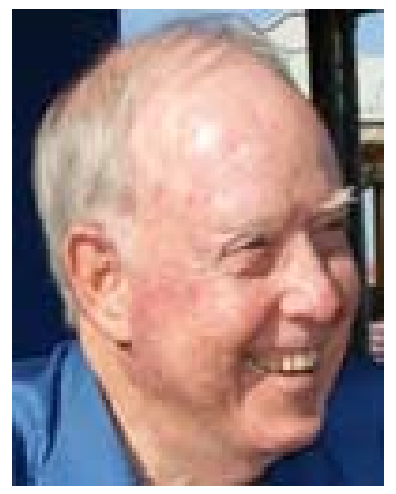

Prof Wallace Taylor is the founding director of The Information Society Institute (TISI), which is currently engaged with the South African Department of Communications e-Skills Institute in addressing national and international issues involved in the social appropriation of ICT for local socio-economic benefits. His current research and praxis interests are focussed on the social appropriation of ICT, public policy development, the role of higher education in the information society and building self-reliance for civil society inclusion. Prof Taylor was named as Citizen of the Year by the City of Rockhampton (Australia) in 2001 for his contribution to community development, the initiation of a range of community and industry events, organisations and programmes. He is co-author of the South African National e-Skills Plan of Action.

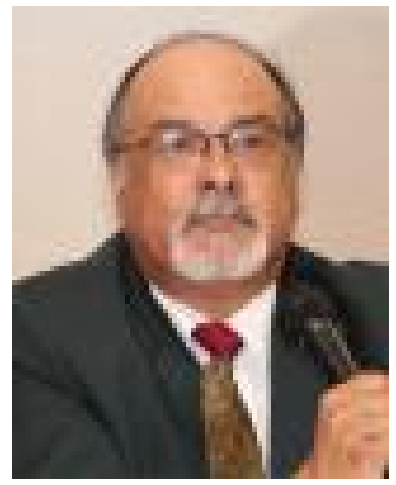

Dr Harold Wesso, Deputy Director General Department of Communications South Africa and acting CEO of the e-Skills Institute (e-SI) and acting CEO of the National Electronic Media Institute of South Africa (Nemisa). He also served as Director General of the Department of Communications during its recent transition peiod. Dr Wesso was previously Deputy Director General in the Premiers Department of the Western Cape Province and oversaw the establishment of the Cape Access Project. Prior to this he was a leading academic and researcher at the University of the Western Cape in Cape Town, South Africa. 